\title{
INTERNAL AUDIT AS A TOOL FOR QUALITY CONTROL OF CUSTOMER SERVICE - CASE STUDY
}

\author{
DANUTA MIERZWA, ${ }^{1}$ MATEUSZ GĘDŁEK \\ ${ }^{1}$ Military Academy of Land Forces in Wroclaw, Faculty of Management, POLAND \\ e-mail:d.mierzwa@wso.wroc.pl
}

RECEIVED
ACCEPTED
JEL
CLASSIFICATION

KEYWORDS

ABSTRACT
8 August 2017

15 December 2017

D01, D02, G01, G11, G15

audit, financial advisory, customer service quality, financial result

The article presents the results of research conducted in a financial advisory firm. The main purpose of the study was to answer the question whether internal auditing improves customer service quality and has an impact on the company's financial performance. The study was conducted in the years 2014-2017. The Authors sought to answer the question by means of a number of research methods and techniques. The first of them was the analysis of source texts, where a variety of expert opinions were confronted over a selected research period, and the results of a survey conducted among financial advisors of the selected company. The presented research has shown unequivocally that improving the quality of customer service by verifying relevant areas through internal audit ensures that a larger number of customers are handled in a comprehensive manner. Consequently, this leads to an increase in profit.

\section{Introduction}

The $21^{\text {st }}$ century in the world economy is a time of high competition for private sector enterprises. This is forced by progressive globalization and the availability of products and services. Commercial entities are geared towards generating higher profits and acquiring new customers. The company investigated by the Authors focuses on financial advice, where the offered products take the form of consultancy services. The company profile requires 
high standards of customer service from the employees. The market offers a customer a large choice of companies that deal with similar services, which imposes the necessity of continuous improvement of various aspects of customer service. Internal audit is one of the effective tools for improving customer service quality. It ceased to be associated only with the control of accounts and currently plays also an advisory function and supports the management in decision-making. It is also a mechanism to improve a company's performance.

The purpose of the study was to answer the question whether internal auditing improves customer service quality and has an impact on the company's financial performance. Audit tools are complex procedures that call for appropriately qualified personnel. The Authors sought to answer the question by means of a number of research methods and techniques. The first one was the analysis of source texts, where a variety of expert opinions were confronted over a selected research period. In the next stage of the research a survey was conducted among financial advisors from the chosen company. The survey targeted 50 employees ( 30 men and 20 women), which accounted for $10 \%$ of the surveyed population. The main purpose of the questionnaire was to answer the question whether financial advisors - audited - also confirm that internal audit improves customer contacts. The results of the research are presented in the tabular and graphical forms.

\section{Definition and international standards for internal audit}

Over the years, numerous definitions of internal audit have emerged, according to the Institute of Internal Auditors (IIA), the internationally recognized definition reads: 'Internal audit is an independent and objective activity of assurance and advisory character, aimed at bringing the added value into an organization and streamlining its functioning. Internal audit supports an organization in achieving the pursued objectives through systematic and consistent activity related to assessing and improving the effectiveness of risk management, control systems and organizational management processes' (Włodarska, 2012, p. 3).

When performing tasks conferred upon them, auditors are obliged to follow the IIA's International Standards for the Professional Practice of Internal Auditing, which fall into three categories:

- attribute standards,

- performance standards,

- implementation standards.

\section{Attribute standaris}

The primary purpose of this type of standards is to clearly specify and define requirements that an organization sets to an internal audit as an organizational unit and an auditor or a group of internal auditors as a professional group as is laid down in the IIA Statute.

\section{Performance standards}

It is important for an auditor to be aware that the results of his/her work should give the added value to an organization. For this to happen the effective organization of work and good technical background are of great importance and the findings should be supported by evidence. The entire internal audit process must be consciously executed and planned so that management can monitor an auditor's progress on an ongoing basis (Czerwiński, 2005, p. 11). 


\section{Implementation/Task execution standards}

In this section the Statute focuses mainly on analyzing and evaluating collected and substantiated information that must be sufficient to achieve objectives of a task. An auditor must characterize himself/herself with pragmatism, accuracy and familiarity with International Standards for the Professional Practice of Internal Auditing as well as others internationally recognized by the international environment of auditors, such as INTOSAI or ISACA standards, i.e. IT auditing standards (Czerwiński, 2005, p. 1; Molski, 2006, p. 162).

\section{Professional approach}

It is of crucial importance that an audit is professionally carried out. A person designated for inspection of a given entity must have general education and specialized qualifications in order to achieve professional excellence. The held certificates are useful for an organization to assess the professionalism of an employee. The especially appreciated ones include:

1. CIA (Certified Internal Auditor).

2. CISA (Certified Information System Auditor).

3. CISM (Certified Information Security Manager).

4. CFE (Certified Fraud Examiner).

An auditor should be credible, transparent, and objective; he/she is expected to observe professional secrecy and acting with due professional diligence (Młodzik, 2013, pp. 199-210).

\section{Characteristics of the selected company}

The start-up of the company under investigation dates back to the year 2000 , when the first such large-scale web portal dealing with the sale of financial products was created. However, the weak informatization of the Polish society and the limited access to the Internet at that time forced a change in the way of operation. The above led to the transformation and change in the operational model, creating the first financial consultancy firm. In its 16 -year history, the company continued to grow in importance in the counseling market and increased its popularity. This made it the largest company of this kind in Poland. In 2015, the company achieved a 10 -fold increase in the net profit compared to the previous year, i.e. up to PLN 18 million. ${ }^{1}$ It shows the size, scale and efficiency in generating high profits for investors and a range of other financial services. Within 15 years the company has developed to such an extent that today it has 90 branches in 50 cities. In 2014, the company mediated in gaining almost PLN 4 billion on terms of mortgage loans, which was an absolute record in Poland for such a short period of time. Already a year later the proprietary investment products offered to clients generated 16 percent of pure income, ${ }^{2}$ which in strategic investments counts in millions of PLN. Great results led to the acquisition of the surveyed Enterprise by Avive, one of the largest companies in the British financial market. This allowed for developing current business structure and introducing the highest international standards based on the Orange Book. The follow-up of the above was the growth of quotations in 2016 as well as the opening of 10 new branches giving an opportunity of real competition with two other largest corporations in the sector, i.e. Tax Care and Open Finance.

\footnotetext{
${ }^{1}$ Retrieved from: http://www.expander.pl/pressroom/17095,conscious.html\#_(28.03.2017).

2 Ibidem.
} 
In Poland the research was conducted in one selected branch. The analyzed branch operates on a franchise basis. The products offered include loans, investments, savings and insurances.

As for the Code of Ethics, the researched firm puts a strong emphasis on relationships with the environment. Shaping contacts with customers must be executed by respecting internal procedures, employees' responsibility for customers and the brand representation, reliable information and searching for the best quality solutions, due care of confidentiality and avoiding behaviors that could discredit the company. There is an official prohibition on insulting competitive firms and the requirement to respect other market players. Rivalry is not to be based on instilling into customers unfavorable opinions about the competition, but only on the appropriate advertising of own products.

Takeover of the researched entity by an international capital group resulted in a number of changes in customer service quality and auditing standards in individual branches. The application of new standards had a positive effect on the company's financial performance as early as in the year the company was turned over.

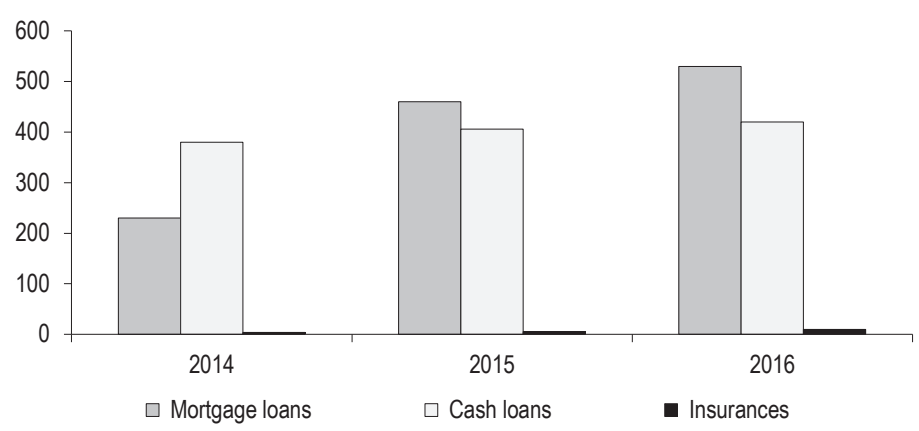

Figure 1. The amount of achieved financial volumes in three consecutive years (expressed in PLN millions)

Source: own study based on press releases from the selected financial advisory company in the years 2014-2016.

The value of volumes achieved in the period under analysis was increasing. The decisions of the company's management and improvement of the customer service quality during the past three years influenced by regular audits of each branch were decisive of development of such a state of affairs.

\section{Financial advisory market}

The financial advisory market in Poland has been growing steadily for several years. Companies operating in this sector achieved very high financial result in 2016. Table 1 depicts the value of mortgage loans paid for the third and fourth quarters of 2016.

Every second mortgage loan in Poland is granted with involvement of a financial intermediary (PricewaterhouseCoopers Audit Company, 2017), which proves the dynamic development of this sector in Poland. The last quarter saw the result by $11 \%$ higher than the previous period, and the value of sold investment products reached PLN 119 million (Table 2). 
Table 1. The value of mortgages sold by the Association of Financial Advisory Companies' members in the third quarter of 2016 and the fourth quarter of 2016

\begin{tabular}{rlcc}
\hline \multicolumn{4}{c}{ Total amount of MORTGAGE LOANS disbursed (in PLN million) } \\
\hline no. & \multicolumn{1}{c}{ company name } & the third quarter of 2016 & the fourth quarter of 2016 \\
\hline 1. & Open Finanse & $1,436.00$ & $1,427.00$ \\
2. & Expander Advisors & $1,272.06$ & $1,352.04$ \\
3. & Notus Doradcy Kredytowi & 516.02 & 491.62 \\
4. & mFinanse & 347.56 & 376.00 \\
5. & Gold Finance & 163.83 & 159.19 \\
\hline Total & & $3,735.47$ & $3,805.85$ \\
\hline
\end{tabular}

Source: Association of Financial Advisory Companies.

Table 2. The value of investment products sold by the Association of Financial Advisory Companies' members in the third quarter of 2016 and the fourth quarter of 2016

\begin{tabular}{clcc}
\hline \multicolumn{4}{c}{ Total amount of INVESTMENT PRODUCTS sold (in PLN million) } \\
\hline no. & \multicolumn{1}{c}{ company name } & the third quarter of 2016 & the fourth quarter of 2016 \\
\hline 1. & Open Finanse & 75.00 & 78.00 \\
2. & Expander Advisors & 32.01 & 41.00 \\
3. & Gold Finance & 0.20 & 0.08 \\
\hline Total & & 107.21 & 119.08 \\
\hline
\end{tabular}

Source: Association of Financial Advisory Companies.

The economic situation in Poland is very dynamic, prompting the Poles to seek solutions that will allow them to invest and multiply their capital. With the help of financial advisors, they can easily and quickly compare the current offer of competing insurance companies and banks (Sawicki, 2013, pp. 81-88). Using consulting services helps a customer to save time and more accurately choose a product that will meet his/her expectations and capabilities. Enterprises also benefit from the services of financial advisors and the value of paid financial loans for the fourth quarter exceeded PLN 395 million.

Table 3. The value of company loans sold by the Association of Financial Advisory Companies' members in the third quarter of 2016 and the fourth quarter of 2016

\begin{tabular}{clcc}
\hline \multicolumn{4}{c}{ Total amount of COMPANY LOANS paid (in PLN million) } \\
\hline no. & \multicolumn{1}{c}{ company name } & the third quarter of 2016 & the fourth quarter of 2016 \\
\hline 1. & Open Finanse & 132.00 & 167.00 \\
\hline 2. & Expander Advisors & 171.18 & 109.83 \\
\hline 3. & mFinanse S.A. & 59.38 & 61.03 \\
\hline 4. & Gold Finance & 10.20 & 30.35 \\
\hline 5. & Notus Doradcy Kredytowi & 25.36 & 27.33 \\
\hline Total & & 398.12 & 395.54 \\
\hline
\end{tabular}

Source: Association of Financial Advisory Companies. 


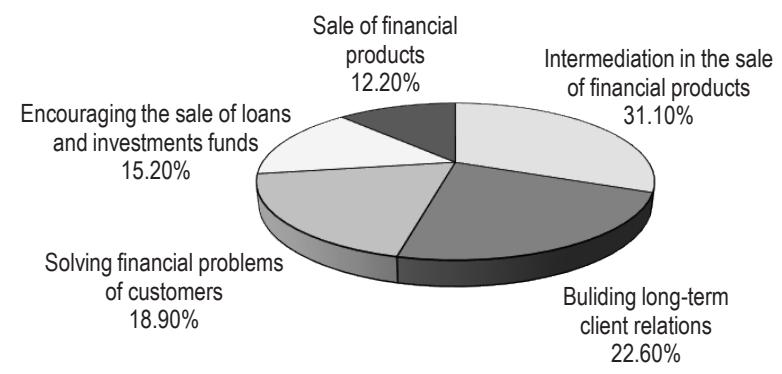

Figure 2. How customers perceive financial advisory services

Source: own study based on Matuszyński (2012), p. 23.

Favorable market conditions, economic development and optimistic economic forecasts for Poland influenced the amount of loans taken by entrepreneurs. The third and fourth quarter of 2016 were exceptionally advantageous for financial advisors in terms of company loans granted (Table 3). This demonstrates the growing importance of financial advice to private and business customers.

In our country, the financial advisory market is relatively young, but very extensive due to the lack of legal regulations. The 'Bankier.pl' portal conducted a survey of 2,281 people who answered questions about aspects of financial advisors' work and the level of satisfaction of services offered.

Almost half of the respondents declared that they were satisfied with financial advisory services in Poland. Only $22 \%$ of respondents were dissatisfied or found the use of advisors' help a waste of time. Such results evidences a high level of customer confidence and may prove that this sector will continue to grow in the future. Financial advisory varies for every customer. Twenty years ago, it was mainly selling insurances or unit linked products, i.e. investing through shares, bonds or investment funds.

Nowadays, the perception of financial advisory has changed. Customers recognize the role of advisers in mediating sales of financial products and building long-term relationships, as confirmed by more than 50 percent of the respondents. One fifth of the respondents perceive counseling as a possible help in solving financial problems. The market is becoming more and more competitive, and only companies that serve customers in a comprehensive way have a chance to succeed (Fiedor, 2014, p. 118). It must be borne in mind that commitments, which a prospective customer takes on when using services of a financial advisor, are usually longstanding. When it comes to credits or investment funds, the duration of commitments and contracts is often ten years or longer, thus customers are very selective about advisors they undertake cooperation with.

With the growing awareness of the Poles about the possibility of using financial advisors, their interest in financial products is also increasing. Customers expect the choice to be continually expanded, which enables better matching services to clients' needs ( $16 \%$ of responses). Customers pay attention to the following aspects: comprehensive knowledge, problem-solving skills (38\% of answers) and high customer service standards ( $30 \%$ of responses) (Figure 3) (Piołunowicz, Wizner, Tomaszewska, 2013, pp. 1-7). 


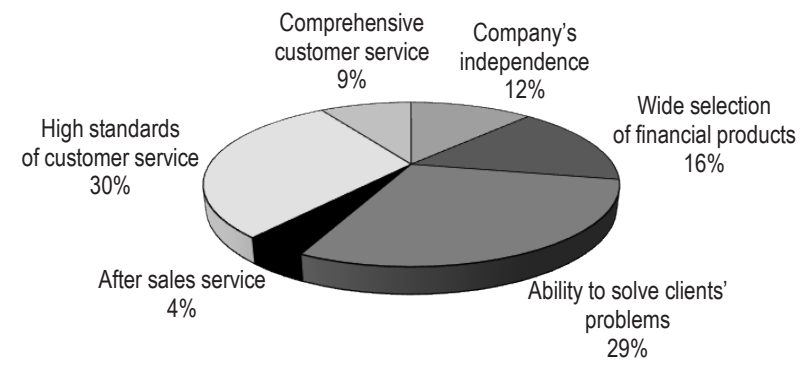

Figure 3. Expectations of customers regarding financial advisory services

Source: own study based on: Matuszyński (2012), p. 24.

The complexity of products offered by banks precludes a thorough familiarization with the offer and the selection of the most advantageous one. In this situation, financial advisors come to the aid, since knowing all the current offers of a bank, they help to make decisions quickly and accurately. Poland is catching up with Western countries, where the services of financial advisers have been used since the 1970s (Waliszewski, 2012, pp. 199-210).

\section{The analysis of selected survey responses}

In 2017, the Authors conducted 50 anonymous personal questionnaires among financial advisers, i.e. persons directly audited. The question: 'Do you feel that regular internal auditing helps to improve customer service in terms of services offered by service advisers?' (Figure 4) was responded unambiguously, $90 \%$ of men and $30 \%$ of women replied positively. The question 'Do you think that customer service quality audits should be performed in the future' received Figure 5.

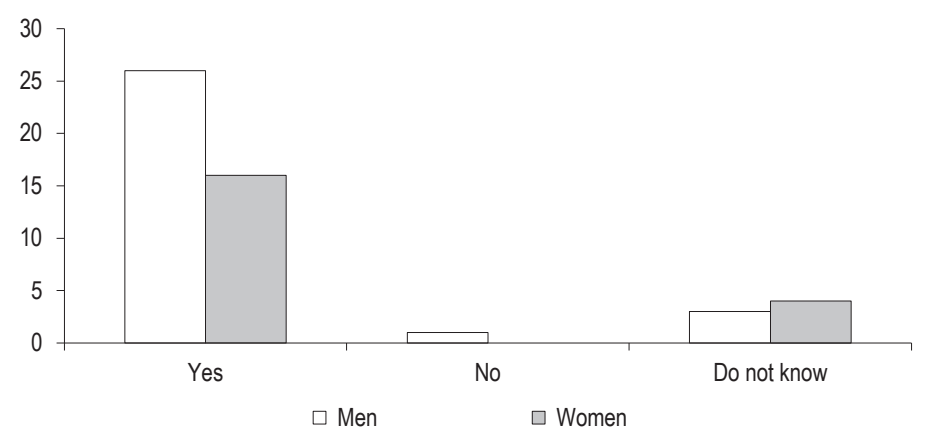

Figure 4. Do you feel that regular internal auditing helps to improve customer service in terms of services offered by service advisers?

Source: own study based on surveys carried out among advisors of the selected financial advisory company. 


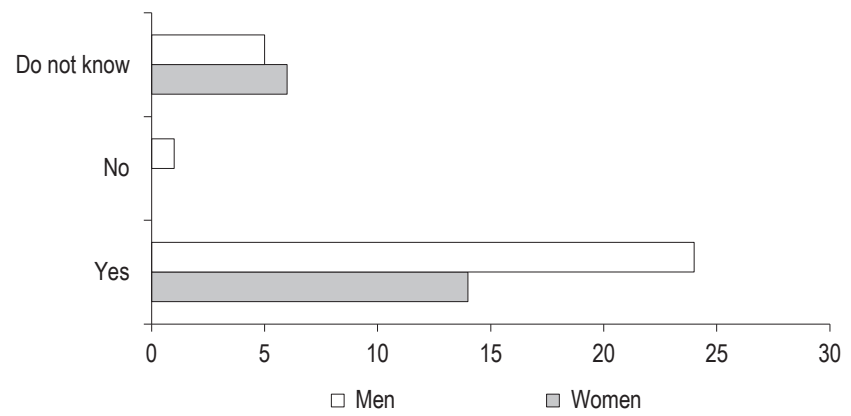

Figure 5. Do you think that customer service quality audits should be performed in the future

Source: own study based on surveys carried out among advisers of the selected financial advisory company.

It can be seen from the above Figure that about $40 \%$ of the surveyed respondents declare that quality customer service audits should be continued in the future.

\section{Conclusion}

Nowadays, the level of services significantly exceeds the quantity of goods offered and therefore it is particularly important to optimize the quality of customer service. The research has shown that verifying relevant areas and gathering information about them can significantly improve customer service. At the same time, the awareness of the management board about the state of affairs of the preparation of advisors for the profession is increasing. It can be said that financial consulting in Poland is a sector with prospects for the future. Undoubtedly, optimizing the quality of customer service can help to achieve a better position in the market and a more competitive offer compared to other companies operating in the sector. The economy of Poland is developing very dynamically and at present the increasing quality of customer service is even obligatory in order to make a company's offer attractive. The above has been also confirmed by the financial results achieved by the analyzed company, which is undoubtedly due to servicing a larger number of customers.

\section{References}

Czerwiński, K. (2005). Audyt wewnętrzny. Warszawa: InfoAudit.

PricwaterhouseCoopers (2017). Raport o sprzedaży kredytów hipotecznych przez pośredników finansowych na zlecenie Związku Doradztwa Finansowego. Wrocław.

Fedor, M. (2014) „Zarządzanie i Finanse Journal of Management and Finance Vol. 12, No. 1/2014 Apetyt na ryzyko jako ważny element Wypłacalności" s. 118

Matuszyński S. (2012). Rynek doradztwa finansowego w Polsce Wrocław. Retrieved from: bankier.pl (27.02.2017).

Młodzik, E. (2013). Audyt wewnętrzny a proces zarządzania ryzykiem. Zarządzanie i Finanse, 1 (11/2), 199-210.

Molski, M. (2006). Przewodnik audytora systemów informatycznych. Warszawa: Helion.

Expander Advisors sp. z.0.0 (2017). Retrieved from: www: http://www.expander.pl/press-room/17095,wiadomosc.html\#news_17095 (28.03.2017).

Piołunowicz, M., Wizner, M., Tomaszewska, M. ( 2013). Jaki audyt jest, każdy widzi, ale czy „każdy” potrafi go właściwie wykorzystać? Przegląd Corporate Governance, 3 (35), 81-98).

Waliszewski, K. (2012). Europejskie Standardy Doradztwa Finansowego w Polsce. Katowice: Uniwersytet Ekonomiczny w Poznaniu. 
Włodarska, K. (2012). Definicja audytu wewnętrznego. Kodeks etyki oraz Międzynarodowe standardy praktyki zawodowej audytu wewnętrznego. Stowarzyszenie Audytorów Wewnętrznych IIA Polska, Warszawa.

Cite this article aS: Mierzwa, D., Gędłek, M. (2018). Internal audit as a tool for quality control of customer service - case study. European Journal of Service Management, 1 (25), 189-197. DOI: 10.18276/ejsm.2018.25-23. 